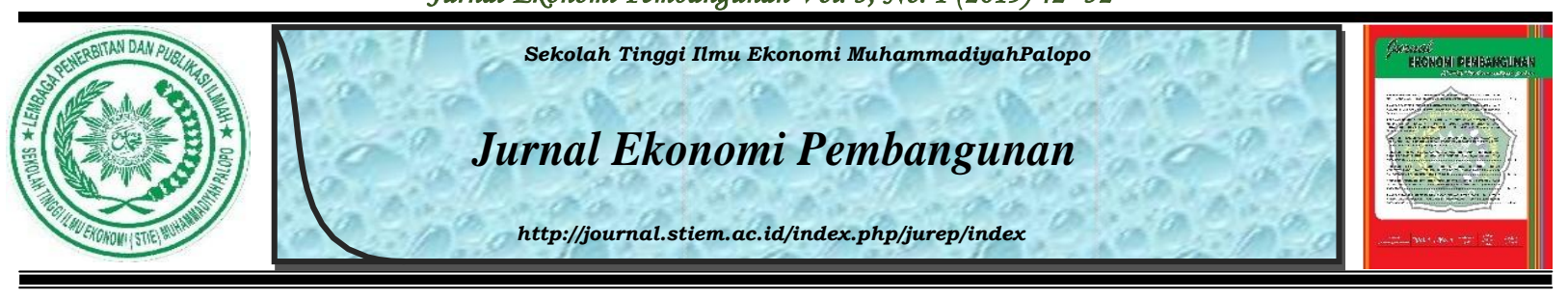

\title{
Pengaruh Kondisi Sosial Dan Pernikahan Di Usia Muda Terhadap Pendapatan Masyarakat (Studi Di Desa Jalajja Kecamatan Burau Kabupaten Luwu Timur) \\ Kasmila
}

STIE Muhammadiyah Palopo

\section{INFO NASKAH}

Diserahkan

11 Mei 2018

Diterima

26 Mei 2018

Diterima dalam revisi

29 Mei 2018

Diterima dan disetujui

10 Juni 2018

\section{Kata Kunci:}

Pendapatan Masyarakat,

Kondisi Sosial Dan

Pernikahan Di Usia Muda

\begin{abstract}
ABSTRAK
Penelitian ini bertujuan untuk mengetahui pengaruh kondisi sosial dan pernikahan di usia muda terhadap pendapatan masyarakat di Desa Jalajja Kecamatan Burau Kabupaten Luwu Timur. Metode pengumpulan data dalam penelitian ini yaitu teknik dokumentasi, wawancara, dan observasi. Penelitian ini bersifat Deskriptif Kuantitatif dengan menggunakan alat Analisis Regresi Linear Berganda. Hasil penelitian bernilai positif, hal ini menunjukkan adanya hubungan positif antara kondisi sosial dan pernikahan di usia muda terhadap pendapatan masyarakat di Desa Jalajja Kecamatan Burau Kabupaten Luwu Timur. Sedangkan analisis yang di lakukan dengan uji t kondisi sosial sebesar 2,674 dan nilai signifikansi yang diperoleh adalah 0,009 $<0,05$ artinya kondisi sosial berpengaruh terhadap pendapatan masyarakat sedangkan pernikahan di usia muda sebesar 0,506 dengan nilai signifikansi yang diperoleh adalah 0,614 >0,05 artinya kondisi ekonomi tidak berpengaruh terhadap pernikahan di usia muda. Pada koefisien derterminasi variansi kondisi sosial dan pernikahan di usia muda sebesar $10,6 \%$ memberikan kontribusi terhadap pendapatan masyarakat sedangkan sisanya $89,4 \%$ dipengaruhi oleh faktor lain yang tidak terdapat dalam penelitian ini. Kemudian hasil analisis korelasi (R) sebesar 0,360 dari hasil diatas menerangkan bahwa ada hubungan yang cukup kuat antara kondisi sosial dan pernikahan di usia muda terhadap pendapatan keluarga. Untuk uji f $f 0.05>$ signifikan 0,005 , dapat disimpulkan bahwa kondisi sosial dan pernikahan di usia nuda secara simultan berpengaruh signifikan terhadap pendapatan masyarakat di Desa Jalajja Kecamatan Burau Kabupaten Luwu Timur.
\end{abstract}




\section{Pendahuluan}

Manusia salah satu makhluk sosial, dimana seorang manusia tidak dapat hidup sendiri tanpa saling berinteraksi dan saling melengkapi antara individu satu dengan yang lainnya, baik dalam bentuk perkumpulan, kelompok maupun organisasi. Salah satu proses dalam membentuk suatu kelompok yaitu dengan adanya perkawinan. Suatu perkawinan bukan hanya menyatuhkan dua keluarga namun dapat menyatukan dua kebudayaan yang berbeda. Perkawinan merupakan hal yang penting bagi setiap manusia, karena dengan sebuah perkawinan manusia dapat memenuhi keseimbangan hidup baik secara sosial, biologis maupun pisikologis.

Dalam sebuah perkawinan akan dijumpai berbagai permasalahan yang menuntut kedewasaan dalam penanganannya sehingga sebuah perkawinan tidak dipandang sebagai kesiapan materi belaka, tetapi juga kesiapan mental dan kedewasaan untuk mengarunginya. Biasanya kondisi dimana pasangan yang tidak sanggup menyelesaikan serta menanggulangi permasalahan yang terjadi dapat menimbulkan berbagai masalah lainnya yang dapat mengarah pada perceraian keluarga. Sehingga banyaknya perkawinan usia muda ini juga berbanding lurus dengan tingginya angka perceraian. Banyaknya kasus perceraian ini merupakan dampak dari mudanya usia pasangan bercerai ketika memutuskan untuk menikah. Namun dalam alasan perceraian tentu saja bukan karena alasan menikah muda, melainkan masalah ekonomi dan sebagainya, tetapi masalah tersebut tentu saja sebagai dampak dari perkawinan yang dilakukan tanpa kematangan diri dari segala aspek. Hal ini disebabkan oleh pengambilan keputusan menikah yang terlalu ringkas dan kurang pertimbangan demi efisiensi waktu sehingga bukan menyelesaikan masalah tetapi menumpuk masalah dengan masalah lainnya.

Resiko perkawinan usia anak berbeda-beda antara satu negara dengan negara lainnya, dengan anak perempuan perdesaan dan miskin sebagai kelompok yang paling rentan terhadap praktik ini. Misalnya, secara global anak perempuan yang berada dalam 20 persen peringkat kesejahteraan terendah 2,5 lebih berisiko untuk dinikahkan pada usia anak dibandingkan dengan 20 persen peringkat kesejahteraan tertinggi. Banyaknya kemungkinan resiko yang terjadi dari segi sosial ekonomi tidak membuat para remaja untuk jeram melakukan pernikahan dini, bahkan banyak remaja yang mengharapkan kebahagiaan dari suatu pernikahan usia muda tanpa mempertimbangkan tingkat kematangan dan kesiapan baik dari 
jasmani maupun rohani serta tidak mengambil nilai-nilai maupun kejadian dari para remaja yang telah lebih dahulu melakukan pernikahan dini.

Selain itu sesuai dengan data yang ditemukan oleh Badan Kependudukan dan Keluarga Berencana Nasional (BKKBN) pada tahun 2014 sampai dengan tahun 2017 menyatakan bahwa jumlah jiwa di Desa Jalajja yang sudah menikah cukup tinggi yakni 48 dari 1000 remaja. Bahkan yang tertinggi di Kalimantan Barat yang mencapai 108 dari 1000 remaja. Angka ini masih jauh dari Rencana Pembangunan Jangka Menengah Nasional (RPJM) 2015, dalam rangka menekan angka pernikahan usia dini yakni sebesar 38 per 1000 remaja. Hal ini juga terjadi di Sulawesi Selatan sebagaimana yang dilangsir oleh rappel.com rabu, 16 Agustus 2017 yang menyatakan bahwa terdapat 333 anak atau remaja yang telah menikah secara resmi selama 2017.

Undang-undang Nomor 1 tahun 1974 pasal 7 ayat (1) tentang perkawinan menyatakan bahwa suatu perkawinan hanya di izinkan apabilah pihak pria mencapai umur sembilan belas tahun dan pihak wanita telah mencapai usia enam belas tahun. Dalam undang-undang tersebut sudah jelas menekankan mengenai pembatasan usia minimal terjadinya suatu perkawinan. Namun, pada kenyataannya hal ini tidak sesuai dengan realita yang terjadi di masyarakat dengan banyaknya pernikahan yang dilakukan pada usia dini khususnya di Desa Jalajja Kecamatan Burau Kabupaten Luwu Timur.

Berdasarkan uraian diatas, maka penulis tertarik untuk mengadakan penelitian dengan judul "Pengaruh kondisi sosial dan pernikahan di usia muda terhadap pendapatan masyarakat Studi Kasus di Desa Jalajja Kecamatan Burau”.

Adapun pokok permasalahan dalam penulisan ini yaitu: Apakah kondisi sosial berpengaruh terhadap pendapatan masyarakat dan apakah pernikahan di usia muda berpengaruh terhadap pendapatan masyarakat.

Tujuan penelitian ini untuk mengetahui pengaruh kondisi sosial terhadap pendapatan masyarakat dan untuk mengetahui pengaruh pernikahan di usia muda terhadap pendapatan masyarakat.

Penelitian ini diharapkan dapat memberikan masukan terhadap masyarakat pada umumnya dan khususnya KUA di Kecamatan Burau agar mengetahui seberapa besar pengaruh sosial dan pernikahan di usia muda terhadap pendapatan masyarakat dan Untuk memberikan informasi tentang seberapa besar pengaruh sosial dan pernikahan di usia muda 
terhadap pendapatan masyarakat.

\section{MetodePenelitian}

\subsection{PendekatanPenelitian}

Metode pengumpulan data dalam penelitian ini yaitu teknik dokumentasi, wawancara, dan observasi. Penelitian ini bersifat Deskriptif Kuantitatif dengan menggunakan alat Analisis Regresi Linear Berganda

Dalam penelitian ini pengumpulan data dilakukan dengan menggunakan metode survey. Survey yang digunakan dalam metode ini berupa kuisoner dan wawancara kepada responden. Kuisoner adalah daftar pertanyaan tertulis yang telah dirumuskan sebelumnya yang akan responden jawab, biasanya dalam alternatif yang definisikan dengan jelas. Dalam penelitian ini akan dibagikan kuisoner yang berisi sejumlah pertanyaan terkait dengan sosial pernikahan di usia muda terhadap pendapatan masyarakat di Desa jalajja Kecamatan Burau.

\subsection{Populasi dan Sampel}

Populasi dalam penelitian ini adalah pendapatan masyarakat di Desa Jalajja Kecamatan Burau yang berjumlah 354 orang yang diambil datanya di KUA Kec. Burau pada tahun 2014 sampai 2017.

Sampel adalah bagian dari jumlah dan karakteristik yang dimiliki oleh populasi (Sugiyono, 2010). Pengambilan sampel dalam penelitian ini dengan teknik probability sampling yaitu proportionate stratified random sampling dengan menggunakan rumus slovin. Menurut Sugiyono (2010), probality sampling adalah teknik pengambilan sampel yang memberikan peluang yang sama bagi setiap unsur.

\subsection{Teknik PengumpulanData}

\section{Analisis Statistik Deskriptif}

Statistik deskriptif memberikan gambaran secara umum mengenai karakter variable penelitian. Sementara itu untuk melihat pengaruh dari variabel-variabel independen (social dan pernikahan di usai muda) terhadap variabel dependen (pendapatan masyarakat) digunakan uji regresi berganda.

Uji Validitas dan Realibilitas

Uji Validitas 
Menurut Sugiono (2012:121) validitas merupakan hasil penelitian yang valid bila terdapat kesamaan antara data yang sesungguhnya terjadi pada objek penelitian.

Uji validitas dilakukan dengan menggunakan teknik Pearson Correlation, yaitu cara menghitung korelasi antara skor masing-masing butir pertanyaan/pernyataan dengan total skor mempunyai tingkat signifikan di bawah 0,05 maka butir pernyataan tersebut dinyatakan valid dan sebaliknya (Ghozali, 2009:49).

Uji Reliabilitas

Reabilitas merupakan adanya konsistensi dan stabilitas nilai hasil skala pengukuran tertentu. Pengujian reabilitas bertujuan untuk mewujudkan sejauh mana suatu pengukuran relative. Konsistensi apabila dilakukan pengulangan penelitian dua kali atau lebih dan juga bertujuan untuk mengukur keandalan dan instrument pengukuran.

Analisis Regresi Berganda

Pengujian hipotesis dalam penelitian ini dilakukan dengan menggunakan analisis regresi berganda. Analisis regresi berganda linear berganda digunakan untuk mengetahui seberapa besar pengaruh variabel bebas (variabel independen) terhadap variabel terikat (variabel dependen) (Sekaran, 2006).

Uji statistik $\mathrm{t}$

Dimaksudkan untuk menguji secara persial diterima atau ditolaknya suatu hipotesis. Hasil output regresi dengan SPSS V.21 akan dilihat $t_{\text {hitung }}$ dan nilai signifikannya. Terdapat

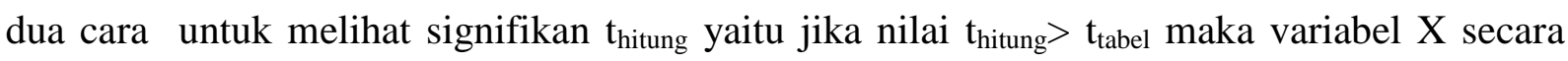
individual (persial) memiliki pengaruh yag signifikan terhadap variabel Y, dan jika nilai $t_{\text {hitung }}<t_{\text {tabel }}$ maka variabel $X$ secara individual (persial) tidak memiliki pengaruh yang signifikan terhadap variabel $\mathrm{Y}$.

Uji F

Menunjukkan apakah semua variabel independen mempunyai pengaruh secara simultan (bersama-sama) antara variabel dependen dengan probabilitas lebih kecil dari 0,05, maka hasilnya signifikan berarti pengaruh dari variabel independen secara bersama-sama terhadap variabel dependen (Ghozali, 2013:16). 


\section{Hasil dan Pembahasan}

\subsection{Hasil}

Keadaan Umum Wilayah Luwu Timur

Kabupaten Luwu Timur merupakan Kabupaten paling Timur di provinsi Sulawesi Selatan. Di mana Kabupaten Luwu Timur ibu Kotanya adalah malili, mempunyai luas wilayah $6.944,88 \mathrm{~km}^{2}$ atau meliputi sekitar 11,14 persen dari luas wilayah Provinsi Sulawesi Selatan. Kabupaten Luwu Timur berada di sebelah Selatan garis khatulistiwa, tepatnya terletak di

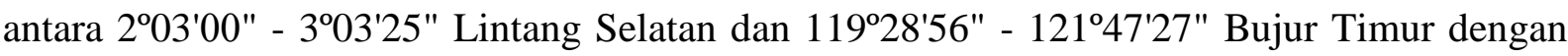
batas-batas wilayah sebagai berikut:

a) Sebelah Utara dan sebelah Timur berbatasan dengan Provinsi Sulawesi Tengah.

b) Sebelah Selatan berbatasan dengan Provinsi Sulawesi Tenggara dan Teluk Bone.

c) Sebelah Barat berbatasan dengan Kabupaten Luwu Utara bulan Maret, mencapai 393 mm dengan jumlah hari hujan sebanyak 24 hari.

Wilayah Kecamatan Burau terdiri dari 15 desa, 66 dusun, dan 117 RT. Kecamatan Wotu terdiri dari 12 desa, 49 dusun, dan 171 RT. Kecamatan Tomoni terdiri dari 12 desa, 45 dusun, dan 108 RT. Kecamatan Tomoni Timur terdiri dari8 desa, 24 dusun, dan 81 RT. Kecamatan Angkona terdiri dari 8 desa, 39 dusun, san 160 RT. Kecamatan Malili tediri dari 17 desa, 46 dusun, dan 135 RT. Kecamatan Towuti terdiri dari 16 desa, 47 dusun, dan 155 RT. Kecamatan Nuha terdiri dari 5 desa, 16 dusun dan 56 RT. Kecamatan Wasponda terdiri dari 6 desa, 28 dusun, dan 90 RT. Kecamatan Mangkutana terdiri dari 9 desa, 31 dusun, dan 124 RT. Dan Kecamatan Kalaena terdiri dari 5 desa, 22 dusun, dan 79 RT.

Profil Desa Jalajja

Desa Jalajja merupakan salah satu desa dari delapan belas desa yang berstatus desa definitive di Kecamatan Burau. Dari luas wilayah Kecamatan Burau yang berjumlah 256,23 $\mathrm{km}^{2}$, sebahagian diantaranya merupakan wilayah Desa Jalajja dengan luas wilayah 14,59 $\mathrm{Ha} / \mathrm{M}^{2}$. Adapun batas-batas Desa Jalajja adalah sebagai berikut:

Sebelah Utara

Sebelah Selatan

Sebelah Barat

Sebelah Timur
: Desa Lambarese.

: Desa Lumbewe.

: Desa Cendana.

: Desa Kalatiri.

Secara umum Desa Jalajja memiliki kondisi topografi berupa dataran tinggi dan 
sebahagian berupa dataran rendah serta rawah. Desa Jalajja terdiri atas enam dusun, dengan rata-rata memiliki tiga rukun tetangga (RT). Pembangunan desa dilakukan berdasarkan nilai yang objektif, berkebijakan, dan strategis. Dalam proses penyusunannya disamping memperhatikan rencana pembangunan jangka pendek dan menengah serta jangka panjang, juga memperhatikan kondisi, potensi, dan aspirasi masyarakat.

Desa Jalajja memiliki jumlah penduduk 4,312 jiwa pada tahun 2014. Namun berdasarkan data 2017 yang berjumlah 4.249 jiwa dapat dilihat bahwa jumlah tersebut terus mengalami penurunan dari tahun-ketahun meskipun tidak mengalami penurunan yang signifikan.

Pada tahun 2017 terdapat 1034 KK, dimana dari data tersebut sebahagian besar penduduknya bermata pencaharian sebagai petani. Selain sebagai petani ada juga bermata pencaharian sebagai wirausaha, kariawan, serta pegawai negeri sipil.

Gambar 1 Struktur Organisasi Desa Jalajja

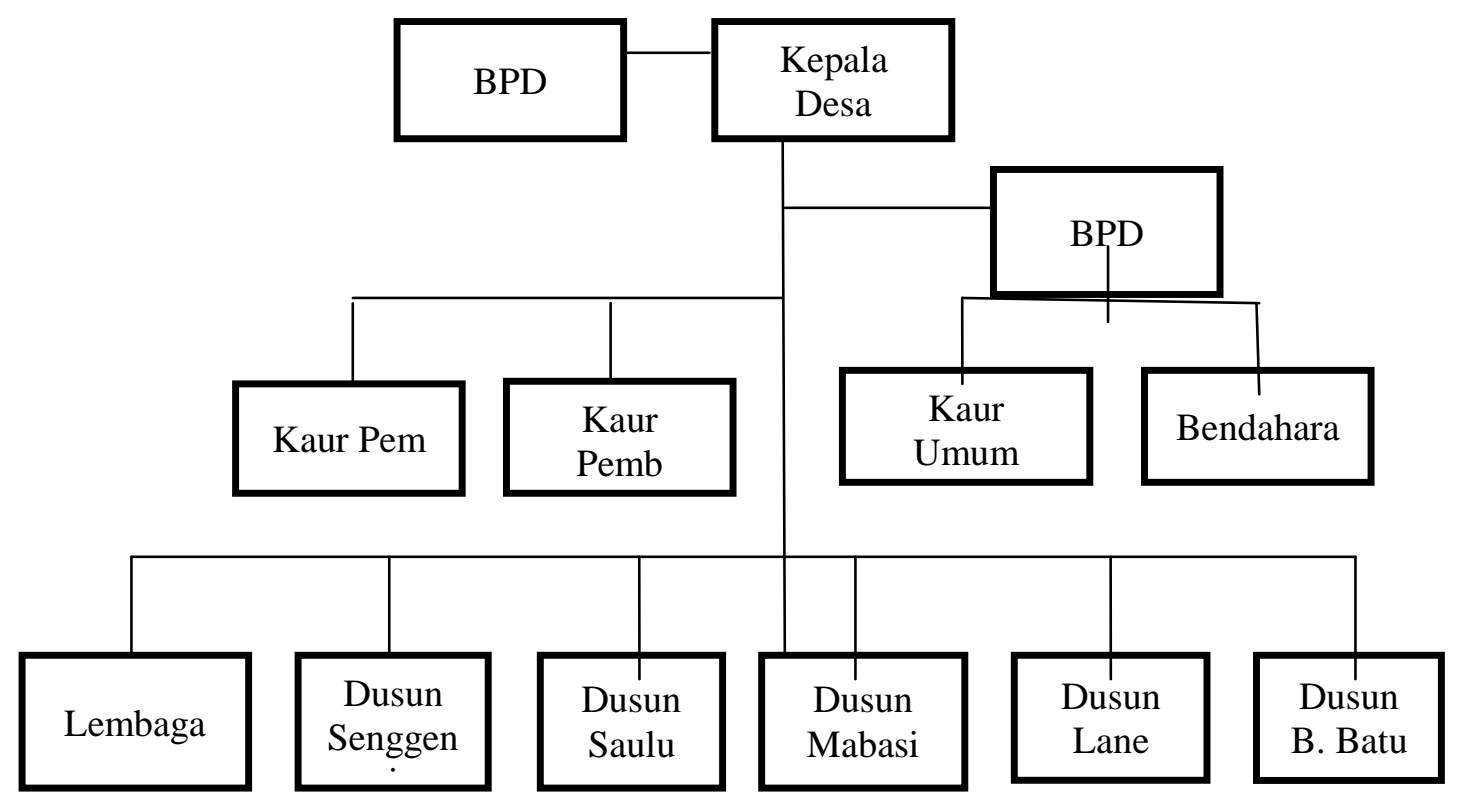

Sumber: kantor Desa Jalajja Kecamatan Burau Kabupaten Luwu Timur 2018

Struktur Organisasi Desa Jalajja terdiri dari Kepala Desa sebagai Kepala Pemerintahan yang dibantu oleh:

1) Unsur staf dan pelayanan yaitu sekdes

2) Unsur pelaksana teknis lapangan (kaur)

3) Unsur wilayah atau pembantu Kepala Desa yaitu Kadus dan RT 


\subsection{Pembahasan}

Pengaruh kondisi sosial dan pernikahan di usia muda terhadap pendapatan di Desa Jalajja Kecamatan Burau Kabupaten Luwu Timur. Setelah dilakukan penelitian dan pengelolaan data pernikahan di usia muda, kondisi sosial dan pendapatan masyarakat di Kabupaten Luwu Timur, dapat disimpulkan bahwa:

Dari hasil uji F diketahui bahwa $f 0.05>$ signifikan 0,005, dapat disimpulkan bahwa kondisi sosial dan pernikahan di usia muda secara simultan berpengaruh signifikan terhadap pendapatan di Desa Jalajja Kecamatan Burau Kabupaten Luwu Timur.

Dari hasi uji t variavel kondisi sosial terhadap pendapatan menunjukkan bahwa nilai $\mathrm{t}$ hitung untuk kondisi sosial sebesar 2,674 dan nilai signifikansi yang diperoleh adalah 0,009, dinyatakan lebih kecil dengan taraf signifikan yang digunakan yaitu 0,05 . Hal ini memberikan indikasi bahwa kondisi sosial secara parsial mempunyai pengaruh signifikan terhadap pendapatan di Desa Jalajja Kecamatan Burau Kabupaten Luwu Timur.

Dari hasil uji t variabel pernikahan di usia muda menunjukkan bahwa nilai t hitung untuk pernikahan di usia muda sebesar 0,506 dengan nilai signifikansi yang diperoleh adalah 0,614 dinyatakan lebih besar dari taraf signifikan yang digunakan yaitu 0,05. Hal ini memberikan indikasi bahwa pernikahan di usia muda secara parsial tidak berpengaruh signifikan terhadap pendapatan di Desa Jalajja Kecamatan Burau Kabupaten Luwu Timur.

Pada koefisien derterminasi didapatkan hasil yang menunjukkan variansi kondisi sosial dan pernikahan di usia muda sebesar 0,106 berarti variansi kondisi sosial dan pernikahan di usia muda sebesar 10,6\% memberikan kontribusi terhadap pendapatan di Desa Jalajja Kecamatan Burau Kabupaten Luwu Timur. Sedangkan sisanya 89,4\% dipengaruhi oleh faktor lain yang tidak terdapat dalam penelitian ini. Kemudian dari hasil analisis korelasi (R) sebesar 0,360 dari hasil diatas menerangkan bahwa ada hubungan yang cukup kuat antara kondisi sosial dan pernikahan di usia muda terhadap pendapatan di Desa Jalajja Kecamatan Burau Kabupaten Luwu Timur.

Hasil penelitian ini diperkuat dengan hasil penelitian sebelumnya yang dilakukan oleh Zulkifli Ahmad (2011) yaqng berjudul Dampak sosial pernikahan usia dini studi kasus di desa Gunung Sindur, Bogor. Menyatakan bahwa pada sangat terbatasnya pengetahuan masyarakat tentang pernikahan usia dini disebabkan mereka hanyalah lulusan Sekolah Dasar dan Sekolah Menengah Pertama, sehingga sumber daya intelektualnya minim sekali. 
Selanjutnya, sejalan dengan penelitian yang dilakukan oleh Rusiani (2013) yang berjudul Pengaruh status ekonomi keluarga terhadap motif menikah dini di pedesaan. Menurut hasil Pernikahan dini terjadi dengan motif remaja untuk memenuhi keamanan, sosial, dan harga diri. Pembentukan identitas terkait pada masa remaja yang menikah dini adalah identitas pembentukan diri yang kuat dan identitas sosial formasi yang lemah.

\section{Simpulan dan Saran}

Berdasarkan hasil pembahasan dari penelitian yang diuraikan oleh penulis pada bab terdahulu di atas, maka pada bab penutup ini telah merumuskan beberapa kesimpulan dan saran dari hasil penelitian ini sebagai berikut:

Dari hasil Koefisien $\beta_{0}$ atau konstanta sebesar 14,921 artinya jika kondisi sosial dan pernikahan di usia muda $\left(\mathrm{X}_{2}\right)$ nilainya adalah 0, maka pendapatan di Desa Jalajja juga akan meningkat sebesar 14,921 .

Dari hasil koefisien determinasi $\left(\mathrm{R}^{2}\right)$ sebesar sebesar 0,106 berarti variansi kondisi sosial dan pernikahan di usia muda sebesar 10,6\% memberikan kontribusi terhadap pendapatan di Desa Jalajja Kecamatan Burau Kabupaten Luwu Timur. Sedangkan sisanya 89,4\% dipengaruhi oleh faktor lain yang tidak terdapat dalam penelitian ini. Kemudian dari hasil analisis korelasi (R) sebesar 0,360 dari hasil diatas menerangkan bahwa ada hubungan yang cukup kuat antara kondisi sosial dan pernikahan di usia muda terhadap pendapatan di Desa Jalajja Kecamatan Burau Kabupaten Luwu Timur.

Dari nilai $\mathrm{t}$ hitung untuk kondisi sosial sebesar 2,674 dan nilai signifikansi yang diperoleh adalah 0,009, dinyatakan lebih kecil dengan taraf signifikan yang digunakan yaitu 0,05. Hal ini memberikan indikasi bahwa kondisi sosial secara parsial mempunyai pengaruh signifikan terhadap pendapatan di Desa Jalajja Kecamatan Burau Kabupaten Luwu Timur.

Dari nilai t hitung untuk pernikahan di usia muda sebesar 0,506 dengan nilai signifikansi yang diperoleh adalah 0,614 dinyatakan lebih besar dari taraf signifikan yang digunakan yaitu 0,05. Hal ini memberikan indikasi bahwa pernikahan di usia muda secara parsial tidak berpengaruh signifikan terhadap pendapatan di Desa Jalajja Kecamatan Burau Kabupaten Luwu Timur

Dari hasil F hitung tersebut diketahui diketahui bahwa $f 0.05>$ signifikan 0,005 , dapat disimpulkan bahwa kondisi sosial dan pernikahan di usia muda secara simultan berpengaruh 
signifikan terhadap pendapatan di Desa Jalajja Kecamatan Burau Kabupaten Luwu Timur.

Berdasarkan hasil penelitian dan pembahasan penulis memberikan saran sebagai berikut:

Pemerintah perlu melakukan peningkatan pendidikan di daerah perdesaan sehingga terjadi perbaikan pola pikir remaja putri maupun orangtua juga peningkatan kesejahteraan masyarakat yang berkaitan dengan peningkatan status ekonomi keluarga.

Kondisi sosial berkaitan dengan dorongan remaja putri untuk lebih diperhatikan oleh pasangan maupun orangtua pasangan, sehingga perlu adanya ketegasan dari orang tua maupun lingkungan dalam mengontrol pergaulan bebas remaja.

\section{Daftar Pustaka}

Achmad Z. 2011. Dampak sosial pernikahan dini jurnal studi kasus di Desa Gunung SindurBogor. (Online), vol: $32 \mathrm{Hal}: 83-87$

(http;//repository.uinjk.ac.id/dspace/bitstream/123456789/21872/1/ ZULKIFLI\%20AHMADFDK.pdf), (Diakses tanggal 12 Desember 2017).

Bayisenge J. 2010. Early marriage as a barrier to girl's education: a developmental challenge in Africa. (online) Vol 28, 4-5. (http://www.ifuw.org/fuwa/ docs/Early-marriage.pdf), (Diakses tanggal 1 desember 2017).

Darmawan dkk, 2010, Faktor-Faktor Yang Berhubungan Dengan Pernikahan Usia Dini Di Kabupaten Purworedjo Jawa Tengah. Jurnal Berita Kedokteran Masyarakal. (online) Vol:25 No.2 Jakarta. (https:wwwscholar.unand.ac.id), (Diakses tanggal 1 Desember 2017).

Deaux K. 2010. Social identity, encyclopedia of women and gender. Malang. Program Pasca Sarjana Univeristas Brawijaya.

Fatchiah E. Kertamuda. Tanpa tahun. Konseling Pernikahan Untuk Keluarga Indonesia. Salemba Humanika.

Firdaus Azhar. 2011. Dampak sosial ekonomi terhadap masyarakat sekitar situ akibat musibah gintung. Jurnal ilmu sosial. (Online), Vol:35, N: 4-18

(http://repository.uinjkt.ac.id/dspace/bitstream/123456789/6078/1/AZHAR\%20FIRDAUS-

FDK.PDF). (Diakses tanggal 5 Desember 2017

Ghozali, Imam. 2013. Aplikasi Analisis Multivariate dengan Program SPSS. Edisi Ketujuh. Semarang : Badan Penerbit Universitas Diponegoro.

Juariyah, 2010. Kondisi Sosial. Jurnal perantara social. (Online), vol:29, No:71

(http://repository.ump.ac.id/1291/3/Uniek\%20Yuniar\%20Vili\%20Hastuti_BAB\%20II.pdf ),(diakses tanggal 4 Desember 2017).

Jannah F. 2012. Pernikahan dini dan implikasinya terhadap kehidupan keluarga pada masyarakat Madura. perspektif hukum dan gender. (Online). Vol: 13 No. 42 (http://ejournal.uin-malang.ac.id/index.php/ egalita/article/view/2113/pdf), (Diakses 
tanggal 1 desember 2017).

Purba RM. 2012. Gambaran Proses Pencapaian Status Identitas Diri Remaja yang Mengalami Kekerasan Fisik pada Masa Kanak-Kanak. Malang: Program paskasarjana Universitas Diponegoro.

Rusiani S, 2013. Motif Menikah Dini dan Implikasinya Dalam Kehidupan Keagamaan Masyarakat Desa Girikarto Kecamatan Tan Panggang Kabupaten Gunung Kidul hal. 28.

Suhadi. 2012. Pernikahan dini, perceraian, dan pernikahan ulang sebuah telaah dalam perspektif sosiologi. Jurnal Komunitas. (Online). Vol: 41, No: 12 (http://journal.unnes.ac.id/nju/index.php/komunitas/article/view/2412/2465) ） (Diakses tanggal 1 Desember 2017).

Sugiyono.(2010). Metode Penelitian Kuantitatif Kualitatif dan $R \& D$

Slovin, (2011). Populasi dan Sampel Penelitian 4 ukuran rumus slovin. (Online). (http:tatangmanguny.wordpress.com/2010/04/19/ukuran-sampel slovin/).(Diakses pada tanggal 01 Desember 2017)

Sekaran, (2006). Research Method For Business, Jakarta : Gramedia Pustaka Utama.

Soekarno. 2011. Pengaruh Faktor Sosial Ekonomi Terhadap Fertilitas Dan Umur Kawin Pertama. Jurnal ilmiah puslitbang KB dan KS. (Online). Vol: 5, No: 4 - 9 Hal 1721 (file://C:/Users/User/Downloads/PERNIKAHAN\%20DINI.pdf) (Diakses tanggal 19 Februari 2018).

Sukirno, Sadono. 2006. Ekonomi Pembangunan . Proses,masalah dan dasar kebijaksanaan. Jakarta : Fakultas Ekonomi UI.

Sadono, Sukirno. 2010. Makro ekonomi. Teori Pengantar. Edisi Ketiga. PT. Raja Grasindo Perseda. Jakarta.

PT Elex Media Komputindo Santoso Singgih. 2013. Statistik Multivariat. Jakarta.

Suparyanto, 2011. Konsep Pernikahan Dini, (online) http://dr-suparyanto.blogspot.com/2011/02/konsep-pernikahan-dini.html (diakses pada tanggal 4 Desember 2018)

UNICEF. 2010. Early Marriage Child Spouses. Innocenti Digest. (Online). No. 7 Hal: 1-30. (http://www. unicef-irc.org/publications/pdf/digest7e.pdf ), (Diakses tangga 15 Desember 2017).

Undang-Undang Nomor 1 Tahun 1974 Pasal 7 ayat 1 tentang perkawinan, Jakarta: Yayasan Peduli Anak Negeri (YPAN). 
